\title{
エスニック・ビジネスの集積過程およびその実態に関する研究 豊島区池袋駅北口周辺における華商を対象として \\ STUDY ON THE PROCESS AND THE ACTUAL CONDITIONS OF THE ETHNIC BUSINESS'S ACCUMULATE
}

A case study of the Chinese merchant in the north area of Ikebukuro station in the Toshima-ku

\author{
劉超*, 後藤春彦**, 佐 藤 宏亮***
}

\section{Chao LIU, Haruhiko GOTO and Hirosuke SATO}

\begin{abstract}
The purpose of this study is to clarify the process of the ethnic business's accumulate and find a new approach to promote the relationship construction between multi-national business operators and local residents in this commercial area in the future.

In this thesis I will clarified the following 2 points:

1)During the last 20 years, the number and geographical distribution of Chinese stores around the north Ikebukuro were changing due to many reasons.

2)The relationship between the Chinese businessmen with the locals was insufficient, which had been a big hindrance to promote the relationship construction among multi-national foreigners.
\end{abstract}

\section{Keywords : Ethnic business, Chinese merchant, Process of the accumulate, Local community エスニック・ビジネス, 華商, 集積過程, 地区コミュニティ}

1. はじめに

1-1 背景

日本の少子化問題やグローバリズムの進展を背景として、留学、就 職などを目的に来日寸る外国人の数が増えている。現在、東京 23 区 の人口の約 $4 \%$ は外国人であり、その内の三分の一以上を中国人が占 めている注 1)。また、2010 年 7 月 1 日から中国人に対する入国管理 が緩和注 2) され、今後日本に定住する中国人が一層増えていくと予 想されている。

在日中国人の増加と共に、中国人によるエスニック集団も形成さ れてきた。例えば、横浜中華街の老華僑たちが自国同胞に向けたサ ービスを提供しはじめ、エスニック・ビジネス注 3 ）（以下 $\mathrm{E} ・ \mathrm{~B} ） の$ 繁栄によって、町全体の振興と地域の観光交流事業の一役を担って きた。その一方で、近年日本に居住する新華僑の増加が見られ、日 本における居住年数が少ないために、日本文化に馴染めなかったり、 地域社会との交流の希薄によるトラブルの発生も少なくない。

今後増加が予想されるエスニック集団と日本人社会との良好な関 係を構築していくための方法論を摸索して行く必要がある。

\section{1-2 目的}

本論文は、豊島区池袋駅北口周辺における華僑による $\mathrm{E} ・ \mathrm{~B}$ を対象 として、以下を明らかにすることを目的とする。

(1) 華商 $\mathrm{E} \cdot \mathrm{B}$ 集積過程と類型

(2) 華商 $\mathrm{E} \cdot \mathrm{B}$ 分布実態とその変遷

(3) 華商 $\mathrm{E} \cdot \mathrm{B}$ 集積要因

(4) 華商 $\mathrm{E} ・ \mathrm{~B}$ の地域社会との関係およびその変化

以上を踏まえ、華商 $\mathrm{E} ・ \mathrm{~B}$ と地域社会との関係の問題点を考察して、 今後地域社会との関係構築の課題を見出す。

\section{1-3 研究方法と研究フロー}

はじめに、2 章では対象地の概要を述べる。3 章では、文献資料や ヒアリング調査から、華商 $\mathrm{E} ・ \mathrm{~B}$ の集積過程を把握し、 $\mathrm{E} ・ \mathrm{~B}$ を類型化 する。 4 章では、華商 $\mathrm{E} \cdot \mathrm{B}$ 経営者へのヒアリング調査によって、時期毎、 類型毎に華商 $\mathrm{E} ・ \mathrm{~B}$ の分布とその変遷を明らかにする。 5 章では、華 商 $\mathrm{E} ・ \mathrm{~B}$ 経営者へのアンケート調查から、時期毎、類型毎に華商 $\mathrm{E} ・ \mathrm{~B}$ 集積要因を分析する。6 章では、ヒアリング調查および華商 $\mathrm{E} ・ \mathrm{~B}$ 経 営者へのアンケート調查によって、華商 $\mathrm{E} ・ \mathrm{~B}$ の時期毎、類型毎の地
* (株)安井建築設計事務所

** 早稲田大学理工学術院建築学科 教授. 工博

*** 早稲田大学理工学術院建築学科 助教 ·博士 (建築学)
Yasui Architects \& Engineers, Inc.

Prof., Dept. of Architecture, Faculty of Creative Sci. and Eng., Waseda University, Dr. Eng. Assist. Prof., Dept. of Architecture, Faculty of Creative Sci. and Eng., Waseda University, Dr. Arch. 
域社会との関係およびその変化を明らかにする。7 章は、4 章，5 章, 6 章の結果から、華商 $\mathrm{E} ・ \mathrm{~B}$ の集積過程における地域社会との関係構 築の問題点をまとめ、更に、今後華商 $\mathrm{E} \cdot \mathrm{B}$ の展望を考察し、地域社 会との関係構築の課題を見出す。

\section{$1-4$. 既往研究と研究の位置づけ}

稲葉 ${ }^{1) 、 2)}$ はエスニック集団の居 住の実態、問題点及び対応、取り組み 状況について明らかにしている。土田 $ら^{3)}$ は東京都内における非永住型の 外国人居住分布と形態について明らか にしている。山下 ${ }^{4)}$ は第二次世界大 戦後の在留中国人の分布及び変化につ いて、華人のエスニックタウンの形 成などを研究している。また、趙ら ${ }^{5}$ ) は華商 $\mathrm{E} ・ \mathrm{~B}$ の成功事例を取り上げ、 華商 $\mathrm{E} ・ \mathrm{~B}$ の発展のプロセス及びソー シャルネットワークの実態と両者の関 連性を明らかにしている。本研究は、 これらの研究を発展させ、華商 $\mathrm{E} ・ \mathrm{~B}$ の集積過程における地域社会との関倸 構築の問題点を考察していることろに 特徵がある。

\section{1- 5 用語定義}

本研究で使用する用語の定義を表 1 に整理した。

\section{2 対象地の概要}

\section{2-1 対象地の選定}

東京 23 区における中国人の分布は、1960 年までは港区が最も多 かったが、終戦後に銀座、新宿、池袋などの繁華街の娛楽業などに 進出寸る老華僑が目立った。1980 年代には中国改革開放政策を背景 に、来日中国人の就学生、留学生が増加し、豊島区が最も多くの在 留中国人を有することになった注 4$)$ 。近年、在留中国人の分布は東 京都の東部および南部へと拡大しているが、1980 年代半ば以降、い わゆる「新華僑」により池袋周辺、中でも北口周辺の商業地区 (池 袋一丁目、二丁目、西池袋一丁目、三丁目）に（図 1)、新華僑が経 営する中国料理店、食品雑貨店、インターネットカフェ、新聞社、 旅行会社等が増加している。今後も、新華僑経営のビジネス事業所 が増加することが予想されるため、本論文では池袋駅北口商業地区 を対象地として選定した。

\section{2-2 対象地概要}

豊島区は、商業、業務機能が集中した副都心池袋を核として、商工 業を中心に発展してきた。近年、グローバリズムの進展を背景に、 多くの外国人が集まる都市交流の結節点となっている。豊島区の外 国人の中で、中国人は半分以上を占めており、その人口は江戸川区、 新宿区に次いで東京都内での第三位となっている。

1980 年代後半以降、「新華僑」の急増に伴い、池袋駅の北口周辺に は新興のチャイナタウンが形成されてきた。現在では、中華料理屋 を初め、食品店、インターネットカフェ、IT 関連、書店および出 版社等のメディア発行注 5) の店舗や事業所は 100 軒近くに及び、同 胞である華人にサービスを提供し、情報を発信する拠点となってい

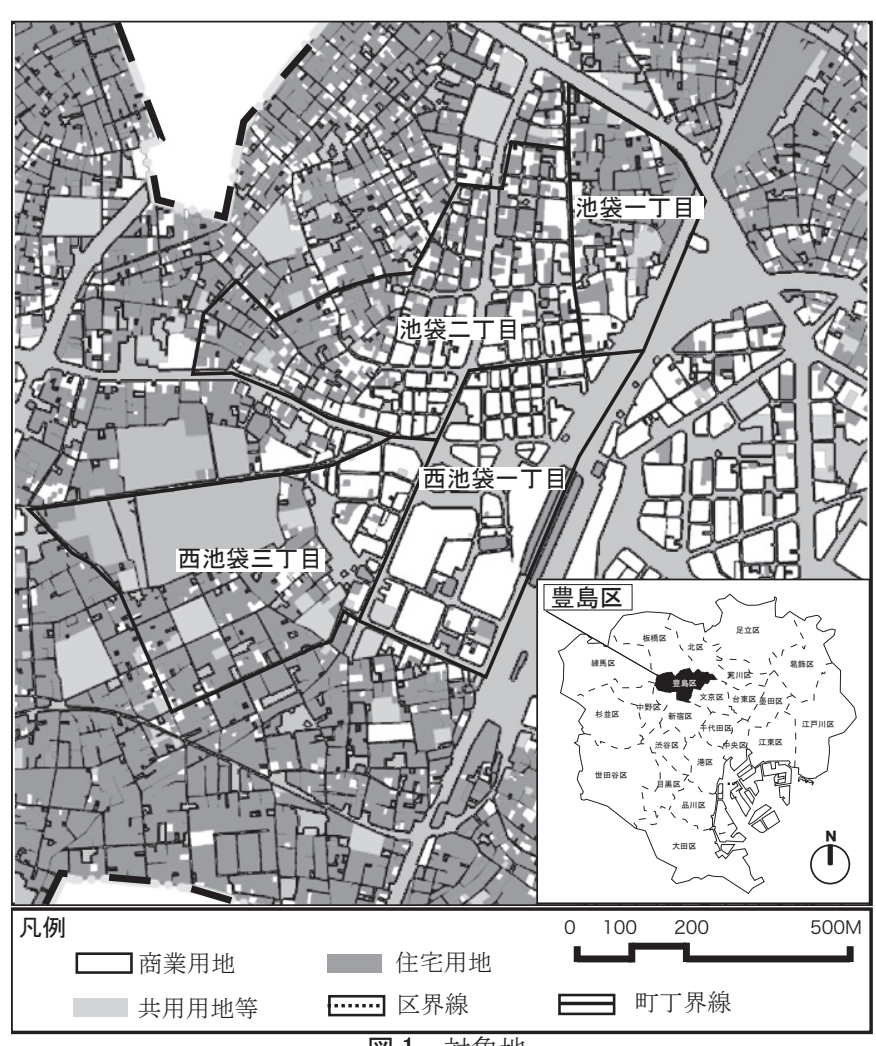

図 1 対象地

る。また、「日本三大中華街」（横浜中華街、神戸南京町、長崎新地 中華街）とは異なる日本の最初のニューチャイナタウン注6) として 位置づけることができる。

\section{3 華商 $\mathrm{E} \cdot \mathrm{B}$ 形成の歴史的経緯、集積過程および類型 3-1 華商 $\mathrm{E} \cdot \mathrm{B}$ 形成の歴史的経緯と集積過程}

池袋は「戦後に長くヤミ市が残り、それこそいろんな人がここで 商売をしていた、だから、ここはひとを自由に受け入れる土壌があ って」15）、「その後、1962 年に池袋西口のヤミ市は撤去されたが、 戦後から入管法改正 (1990 年) までに、池袋西口周辺の自由な土壌 の中で老華僑による商売は存在していたのではないかと考えている」 注 7) という状況であった。1990 年までに、開業した華商 $\mathrm{E} ・ B$ の数 および業種の調查は、ヒアリング調査によれば 3 件のみとなってい るが (図 2)、経営者の入れ替わりも数回行われ、事業所の開業初期 の実情をつかむことは容易ではない。

日本語学校の多くは東京に集中しているが、中でも池袋周辺には多 数の日本語学校が立地し、アルバイトの機会も多いために中国人就 学生が居住するようになり、1987 - 1988 年の豊島区の在留中国人 の激増を招いた (図 3)。1989 年に発生した天安門事件による出国制 限の影響で、新たに訪日寸る中国人が急減したが、1990 年の入管法 改正以降、豊島区では中国人居住者は増加に転じ ${ }^{4)}$ 、新華僑による $\mathrm{E}$. B が増加した。バブル崩壊後に事業所用物件の空室が目立つように なったことは、池袋新華商 $\mathrm{E} ・ \mathrm{~B}$ 出現の要因の一つと考えられる ${ }^{10)}$ 。 その後、日本政府が就学・留学ビザの資格審査を厳しくすると、豊 島区における在留中国人は減少したが、1998 年から再び増加に転じ ている。それに伴い、1998 - 2006 年の間に、池袋の華商 $\mathrm{E} ・ \mathrm{~B}$ 新規 事業所数は毎年 2 件以上に増えている。2006 年になると、豊島区に 


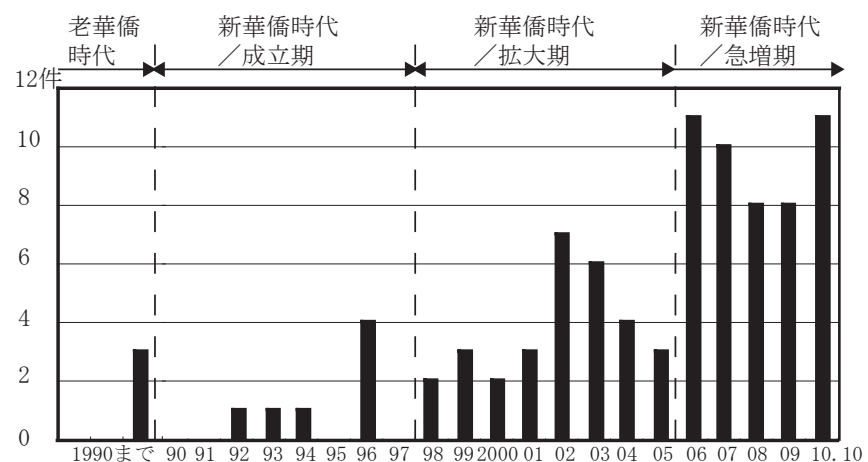

図 2 池袋の華商 $\mathrm{E} ・ \mathrm{~B}$ の開業数の推移 (資料 : ヒアリング調査により作成)

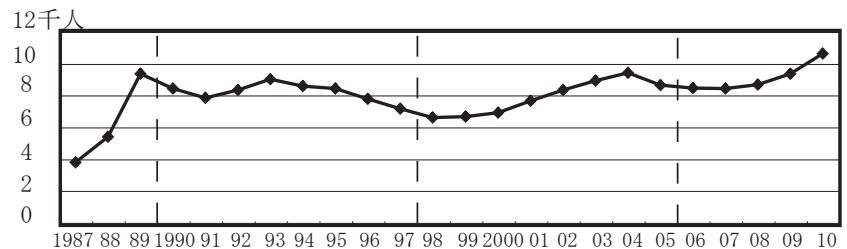

図 3 豊島区における中国人の登録数 (資料: 東京都総務局統計資料により作成)

おける在留中国人は再び増加に転じ、東京の華人社会は新華僑が中 心となっている注 12 2)。2006 年以降、対象地における新規事業所の 数は毎年 8 件以上であり、2006 年から 2010 年の間の新規事業所数 は 48 件であって、全数の半分以上を占めている。

以上から、池袋北口周辺における華商 $\mathrm{E} ・ \mathrm{~B}$ 集積の過程は、1990 年までの「老華僑時代」と 1990 年の入管法改正以降の「新華僑時代」 の二つに分けられる。そして、「新華僑時代」は「成立期」（1990 1997)、「拡大期」（1998 - 2005）、「急増期」（2006 一）の 3 期に区 分できる。華商 $\mathrm{E} ・ \mathrm{~B}$ 事業所の増加は「新華僑時代」から本格に始ま っており、それに伴い、地 域社会との関係が変化して くると考えられ、本稿は「新 華僑時代」以降の華商 $\mathrm{E} ・$ B を中心に考察する。

3-2 立地分布形態によ る華商 $\mathrm{E} \cdot \mathrm{B}$ の類型

本稿では、池袋駅北口周 辺における華商 $\mathrm{E} ・ \mathrm{~B}$ 事業 所の分布に着目し、事業所 の性格を強く反映するもの として、立地環境を指標と して分類を行った。

池袋駅北口周辺地区は大 通り（劇場通り）によって 分断され、大通りを挟ん で駅と反対側を「駅西立 地」として分類した。さら に、容易に歩行できる距離 注 13 ）を考察して、駅側の エリアを「駅前立地」と「駅 北立地」の二つに分類した （図 4、N =94）。各類型の 事業所の業種注 $14 ）$ を表 2
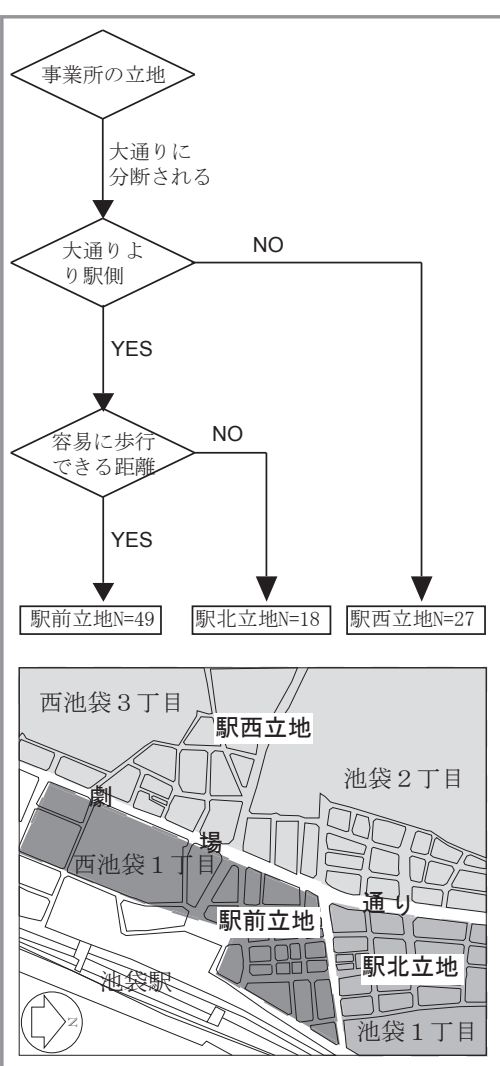

図 4 事業所分類のフロー

に示した。

「駅前立地」は、池袋「副都心商業業務地区」に立地する店舗であり、 49 件の事業所が該当して、全体の半分以上を占める。業種は飲食業、 小売業の電話通信機材販売を始め、多様な業種が雑居ビルに存在し ている。これは池袋界隈の多面性と華商 $\mathrm{E} ・ \mathrm{~B}$ 分布の雑然性を表わし ている ${ }^{10)}$ 。

表 2 事業所類型別にみた商華 $\mathrm{E} ・ \mathrm{~B}$ 事業所の業種

\begin{tabular}{|c|c|c|c|}
\hline 事業所類型 & 駅前立地 & 駅北立地 & 駅西立地 \\
\hline 事業所数 (件) & 49 & 18 & 27 \\
\hline $\begin{array}{l}\text { 業種及び事業 } \\
\text { 所数（件） }\end{array}$ & 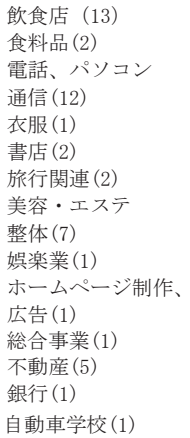 & 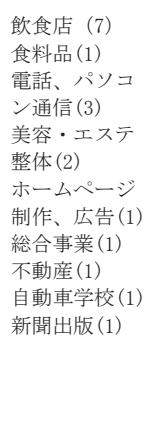 & 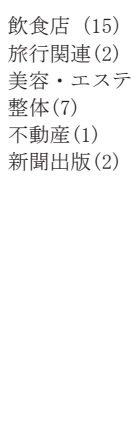 \\
\hline
\end{tabular}

「駅北立地」は 18 件であり、飲食業を始め、業種も多様であるが、 「駅前立地」と比べて数はかなり少ない。駅までの距離の影響が表れ ていると考えられる。

「駅西立地」は 27 件であり、飲食店と美容エステが数多く立地し ている。

\section{4 集積過程における華商 $\mathrm{E} \cdot \mathrm{B}$ の分布とその変遷}

\section{4-1 華商 $\mathrm{E} \cdot \mathrm{B}$ の空間分布と類型毎の事業所の変遷}

94 件の華商 $\mathrm{E} ・ \mathrm{~B}$ 事業所の経営者をヒアリング調査対象として（表 3 )、、新華僑時代」に当たる 85 件の事業所の開業時期を得た（表 4 ）。 開業時期毎の空間分布を図 5 に示す。

\section{表 3 ヒアリング調査の概要}

\begin{tabular}{|c|c|c|c|}
\hline \multicolumn{2}{|r|}{ 調査1 } & \multicolumn{2}{|r|}{ 調査2 } \\
\hline 対象者 & 94件の華商E・Bの経営者 & I 対象者 & $\begin{array}{l}94 \text { 件の華商E・Bの経営者 } \\
\text { (有効回答 : } 85 \text { 件) }\end{array}$ \\
\hline 調查方法 & 対面インタビュー形式 & l調査方法 & 対面インタビュー形式 \\
\hline 調査時間 & 2010.5.1-2010.5.31 & , 調查時間 & 2010.9.14-9. 22 \\
\hline 調査内容 & $\begin{array}{l}\text { 華商E・Bの情報と立地 } \\
\text { 場所の変遷を確認 }\end{array}$ & I 調査内容 & 事業所の開業時期 \\
\hline
\end{tabular}

\section{1 ) 成立期}

「駅前立地」が分散して、増加していることが分かった。

2 ）拡大期

各類型毎に事業所の数は増加 し、「駅北立地」と「駅西立地」 の事業所が分散している一方、 「駅前立地」は集中し始めている。 3 ) 急増期

「駅前立地」は、既存の店舗の
表 4 類型毎の事業所の増加数

\begin{tabular}{|c|c|c|c|c|}
\hline 時代 & 類型前立地駅北立地駅西立地合計 \\
\hline 成立期 & 6 & 0 & 1 & 7 \\
\hline 拡大期 & 14 & 6 & 10 & 30 \\
\hline 急增期 & 26 & 11 & 11 & 48 \\
\hline
\end{tabular}



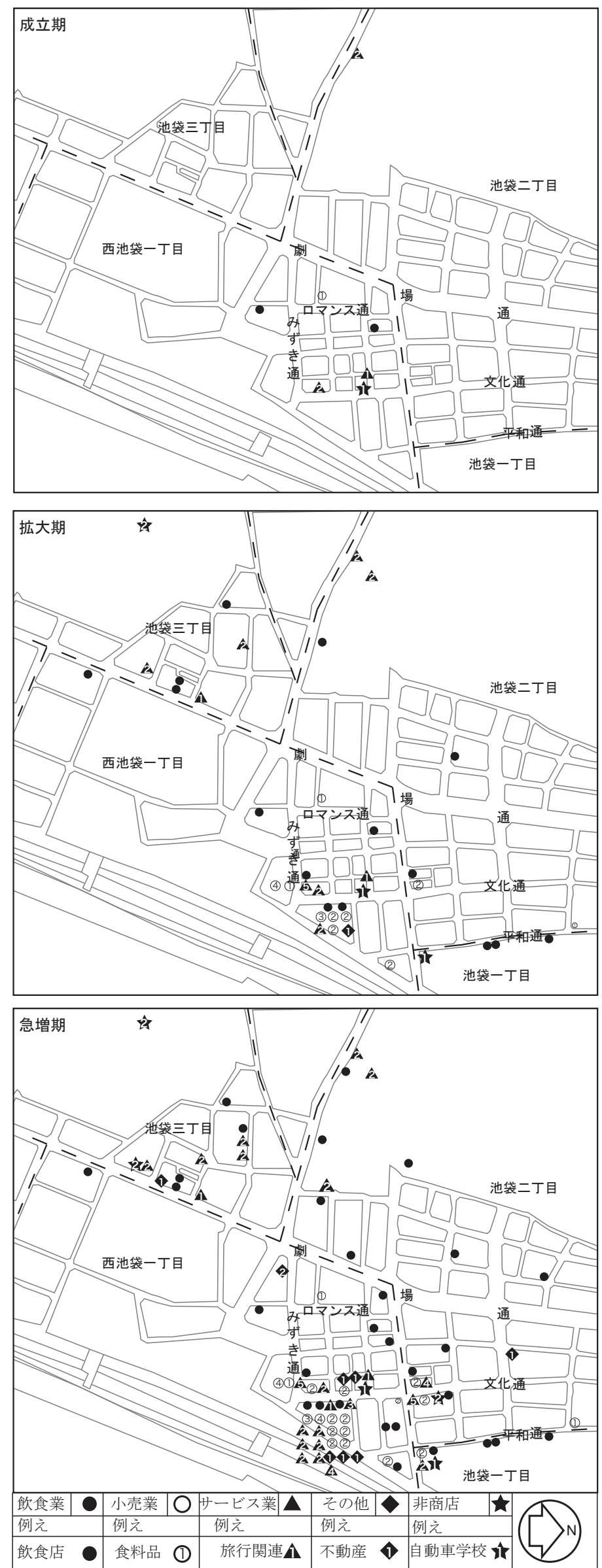

図 5 時期毎の事業所の空間分布 (資料: 聞き取り調查により作成)

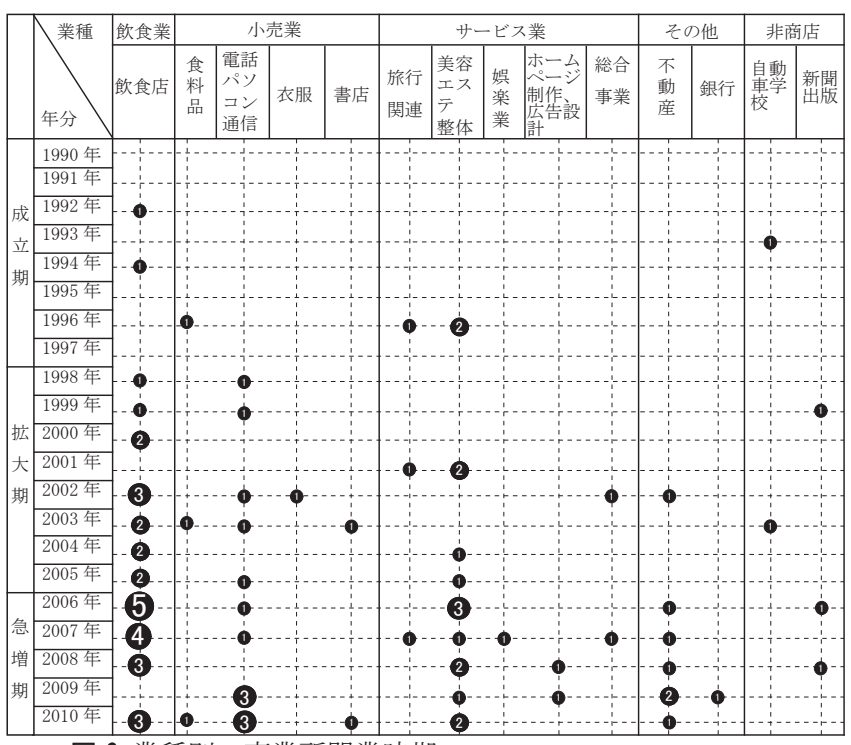

図 6 業種別の事業所開業時期（資料：ヒアリング調查により作成）

周辺にどんどん集中していく。また、「駅北立地」は、文化通り、平 和通り沿いにある程度集中している。一方で、「駅西立地」の事業所 は既存の店舗から離れて、周辺へ分散する傾向がみられる。

\section{4-2 時期毎の業種変化}

ヒアリング調査によって、得られた業種別の事業所開業時期を図 6 に示す。

\section{1 ）成立期}

1990 年の入管法改正直後、新華僑の急増と共に、小売業の食料品 を販売する事業所が開業してきた。また、中国人の滞在・定住化が 一層進展し、自動車学校、旅行関連、新聞社等が華商 $\mathrm{E} ・ \mathrm{~B}$ に加わった。 2 ) 拡大期

飲食業と美容エステが顕著に増加する。2000 年以降、パソコンの 普及と共に、パソコン及び通信機材の販売を開始する事業所が見ら れるようになった。

\section{3 ）急増期}

飲食業、美容エステは更に増 加している。同時に、小売業や 不動産業の事業所が増えている。 近年、華商 $\mathrm{E} ・ \mathrm{~B}$ の増加とともに、 金融機関や総合事業会社や広告 会社といったかなり高いサービ スを行う事業所も開業している。 4-3 業種毎の事業所類型の変 化

業種毎の事業所類型の経年変 化を表 5 に示す。

「飲食業」は「駅前立地」から 「駅北立地」、「駅西立地」への拡 大がみられる。

「小売業」は「駅前立地」の増 加が目立ち、「駅北立地」の増加 も見られる。一方で、「駅西立地」 に「小売業」が存在していない
表 5 業種毎の新規事業所類型

\begin{tabular}{|c|c|c|c|c|}
\hline & $\begin{array}{l}\text { 歌前 } \\
\text { 立地 }\end{array}$ & 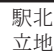 & $\begin{array}{l}\text { 駅西 } \\
\text { 立地 }\end{array}$ \\
\hline & 飲食業 & 2 & & \\
\hline & 小売業 & 1 & & \\
\hline 立 & サービス業 & 2 & & 1 \\
\hline & その他 & & & \\
\hline & 非商店 & 1 & & \\
\hline \multirow{5}{*}{$\begin{array}{l}\text { 拡 } \\
\text { 期 }\end{array}$} & 飲食業 & 4 & 4 & 5 \\
\hline & 小売業 & 7 & 1 & \\
\hline & サービス業 & 2 & & 4 \\
\hline & その他 & 1 & & \\
\hline & 非商店 & & 1 & 1 \\
\hline \multirow{5}{*}{ 急增 } & 飲食業 & 6 & 3 & 6 \\
\hline & 小売業 & 7 & 3 & \\
\hline & サービス業 & 8 & 3 & 3 \\
\hline & その他 & 4 & 1 & 1 \\
\hline & 非帝 & 1 & 1 & \\
\hline
\end{tabular}


ことが分かった。

「サービス業」は「拡大期」に「駅前立地」から「駅西立地」へ、急 増期」に再び「駅前立地」と「駅北立地」一増加傾向が変化する。

それ以外の業種は「駅前立地」の事業所を中心に増加しながら、「駅 北系」と「駅西系」の事業所も増えている。

\section{4-4 小結}

池袋北口周辺における華商 $\mathrm{E} ・ \mathrm{~B}$ は「急増期」から事業所の増加が 顕著にみられる。その内、「駅前立地」は多様な業種の事業所が同時 に増加しながら、池袋駅の北口の近辺へ集中していく。「駅北立地」 は多様な業種が分散して、「文化通り」や「平和通り」沿い一集中寸 る勢いが表れている。「駅西立地」は飲食業を中心として、既存店舗 から離れて、周辺へ分散し、増加している。

\section{5 経営主体からみた華商 $\mathrm{E} ・ \mathrm{~B}$ の集積要因}

華商 $\mathrm{E} ・ \mathrm{~B}$ が池袋に集積した要因を明らかにするため、華商 $\mathrm{E} ・ \mathrm{~B}$ 経 営者を対象にアンケート調查を行った。概要を表 6 に示寸。

表 6 アンケート調査の概要

\begin{tabular}{|l|l|l|}
\hline \multicolumn{2}{|c|}{ 調査概要 } & \multicolumn{1}{c|}{ 調査内容 } \\
\hline 対象者 & 88 件の華商E・Bの経営者 & 出店理由 \\
\hline (池袋選定理由、 \\
調査方法 & 直接配布 $/$ 回収によるアンケート事業所立地選定理由) \\
\hline 調査時間 & $2010.9 .23-2010.10 .15$ & (地域社会との埌が組織、近隣事業主) \\
\hline 配布枚数 & 88 事業所の特徵 \\
\hline 回答 & 53 枚 & (開業時期、業種、社員と客の構成) \\
\hline 回収率 & $60.20 \%$ & 今後の展望 \\
\hline
\end{tabular}

\section{5-1 池袋を選定した理由}

華商 $\mathrm{E} ・ \mathrm{~B}$ 経営者が池袋を選定した理由をアンケート調査（複数回 答可）により把握した。これらの理由を「物理要素」、人間要素」、社 会要素」の 3 つ項目（図 7）毎に分析して、池袋北口周辺が華商 $\mathrm{E}$ ・ B を支える要素を明らかにする。

「人間要素」においては、53 件のうち「狙いの客層が多い」が 40 件であった。次いで、「人通りが多い」が 32 件、「同胞の経営者の集 積と近さ」が 22 件、同胞による労働力の充実」が 3 件の順となった。

次に、「物理要素」については、「公共交通が便利」が 35 件、「飲 食業や小売店の充実」が 13 件、「経営者の居住地に近い」が 0 件と なった。池袋駅は都心と郊外との交流の結節点として、通勤や通学

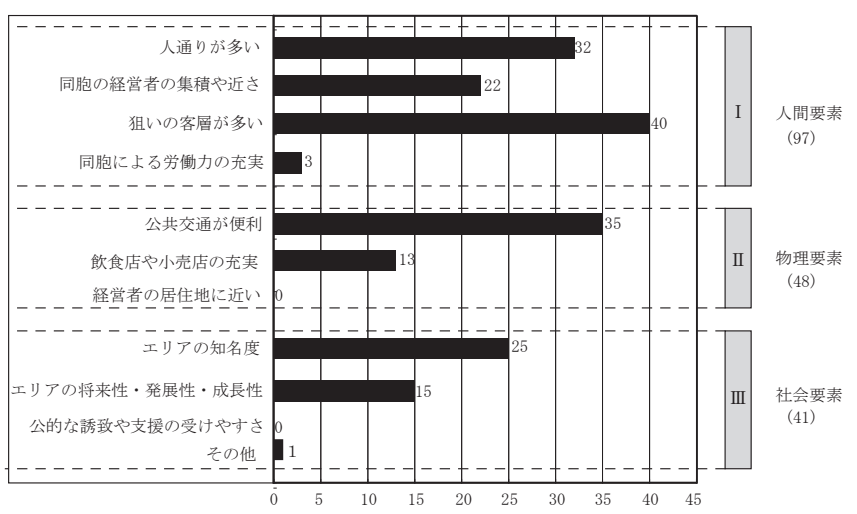

図 7 池袋を選定した理由
などの便利さにより、中国人を客層とするポテンシャルがあると考 えられる。

最後に、「社会要素」については「エリアの知名度」が 25 件、「エ リアの将来性・発展性・成長性」が 15 件となった。しかし、「公的 な誘致や支援の受けやすさ」という選択肢の結果は 0 件であり、華 商 $\mathrm{E} ・ \mathrm{~B}$ は公的な誘致や支援を重視していなかったことがわかる。

また、池袋を選定した主な理由の時期毎の変化を表 7 に示す。「成 立期」は「公共交通が便性」が重視され、「拡大期」から「狙いの客 層が多い」が一番目の理由になった。また、「エリアの知名度」が注

表 7 時期毎に池袋を選定した主な理由の変化

\begin{tabular}{|c|c|c|c|}
\hline & 成立期 & 拡大期 & 急増期 \\
\hline 番目 & 公共交通が便利 (5) & 狙う客層が多い（14） & 狙う客層が多い（22） \\
\hline 二番目 & 人通りが多い (4) & 人通りが多い（11） & 公共交通が便利（19） \\
\hline 三番目 & $\begin{array}{l}\text { 飲食店や小売店 } \\
\text { 㚏䒠 (3) }\end{array}$ & 公共交通が便利（10） & 同胞の経営者の集積や近さ（16） \\
\hline 四番目 & 狙う客層が多い（3） & エリアの知名度 (6) & 人通りが多い（14） \\
\hline
\end{tabular}

目され、華商 $\mathrm{E} ・ \mathrm{~B}$ の影響力が大きくなっていると言えるだろう。「急 増期」から、「同胞の経営者の集積と近さ」が重視され、空間分布の 集中がみられる。

\section{5-2 池袋内において事業所の立地場所を選定した理由}

近年池袋北口周辺における華商 $\mathrm{E} ・ \mathrm{~B}$ 立地分布の動向に影響する要 因を明らかにするため、事業所の立地場所を選定した主な理由を時 期毎と類型毎に考察し、その結果を表 $8 、 9$ に示した。

表 8 時期毎の事業所の立地場所を選定した主な理由

\begin{tabular}{|c|c|c|c|}
\hline & 成立期 & 拡大期 & 急増期 \\
\hline 一番目 & 客がゆっくり歩ける（6) & 客がゆっくり歩ける（8) & 客がゆっくり歩ける（18） \\
\hline 二番目 & $\begin{array}{l}\text { 近辺に同胞による店舗 } \\
\text { 多い (5) } \\
\end{array}$ & $\begin{array}{l}\text { 近辺に同胞による店舗 } \\
\text { が多い（7) }\end{array}$ & $\begin{array}{l}\text { 近辺に同胞による店舗 } \\
\text { が多い (7) }\end{array}$ \\
\hline 三番目 & 駅からの近さ（2） & 駅からの近さ（7） & 駅からの近さ（7） \\
\hline 四番目 & 低層階である（2） & $\begin{array}{l}\text { 街並みや景観などが醸し } \\
\text { 出イメージや雰囲の的の } \\
\text { よさ (3) }\end{array}$ & 使用面積の広さ（4） \\
\hline
\end{tabular}

「成立期」から、「客がゆっくり歩ける」ことが一番の理由に転じて おり、繁華街における集客力を高めるために歩行者道路空間や環境 を重視していることが伺える。「拡大期」から、「近辺に同胞による 店舗が多い」ことが再び重視され、「急増期」から、「駅までの近さ」 が重視されている。これは、池袋駅北口近辺の集積実態に反映され ている。また、近年、使用面積の広さ」が重視され始めているが、「低 層階である」ことはあまり重視されていない。

「駅前立地」と「駅西立地」は「客がゆっくり歩ける」や「近辺に 同胞による店舗が多い」という理由が多いが、「駅前立地」はそれと ともに「駅までの近さ」が重視されるのに対して、駅西立地」は「隠

表 9 類型毎の事業所の立地場所を選定した主な理由

\begin{tabular}{|c|c|c|c|}
\hline & 駅前立地 & 駅北立地 & 駅西立地 \\
\hline 一番目 & 客がゆっくり歩ける（18) & $\begin{array}{l}\text { 近辺に同胞による店 } \\
\text { 舗が多い (17) }\end{array}$ & 客がゆっくり歩ける（8） \\
\hline 二番目 & $\begin{array}{l}\text { 近辺に同胞による店 } \\
\text { 舗が多い (17) }\end{array}$ & \multirow{2}{*}{$\begin{array}{l}\text { 客がゆっくり歩ける（6) } \\
\text { 駅からの近さ（6） }\end{array}$} & $\begin{array}{l}\text { 近辺に同胞による店 } \\
\text { 舗が多い (6) }\end{array}$ \\
\hline 三番目 & 駅からの近さ（16） & & 隠れた家の雰囲気（6） \\
\hline & 低層階であること（3） & \begin{tabular}{|l|} 
使用面積の広さ (2) \\
近边に駐車場がある (2)
\end{tabular} & 駅からの近さ（5） \\
\hline
\end{tabular}


れた家の雾囲気」が重視されている。一方で、「駅北立地」は「近辺 に同胞による店舗が多い」という理由が最も多い。また、「駅前立地」 は「低階層であること」が重視されるが、「駅北立地」は「使用面積 の広さ」や「近辺に駐車場がある」という要素が重視されている。

\section{5-3 小結}

池袋における華商 $\mathrm{E} ・ \mathrm{~B}$ を支える主な要素としては、対象とする客 層としての自国の同胞の集積に加え、公共交通の利便性および人通 りの多さという条件が大きく影響していることがうかがえる。また、 華商 $\mathrm{E} ・ \mathrm{~B}$ は様々な理由で事業所の立地場所を選定していくが、その 結果、「駅からの近さ」が重視される「駅前立地」の同胞集積は更な る集中を生み、「近辺に同胞による店舗が多い」ことを立地選定の理 由とする「駅北立地」は集中を加速していく傾向がある。また、「隱 れた家の雰囲気」であることが求められる「駅西立地」では、周辺 一分散していく傾向がみられると言える。

\section{6 華商 $\mathrm{E} \cdot \mathrm{B}$ の地域社会との関係とその問題点}

華商 $\mathrm{E} ・ \mathrm{~B}$ の地域社会との関係とその問題点について、事業所選定 の仲介者、近隣商店主や地縁組織との慗がりおよび華商 $\mathrm{E} ・ \mathrm{~B}$ 間のネ ットワークの動きをヒアリング調查及びアンケート調查（複数回答 可）によって把握し、以下に整理した。

\section{6-1 事業所選定の仲介者}

事業所選定の仲介は主に「不動産」と「業務関係者」であり、「拡 大期」は「不動産」を仲介するものが一番多かったが、「急増期」に 入って、「不動産」の割合が減って、「業務関係者」、「ネットサイト」 などが増えていることがわかった（図 8)。

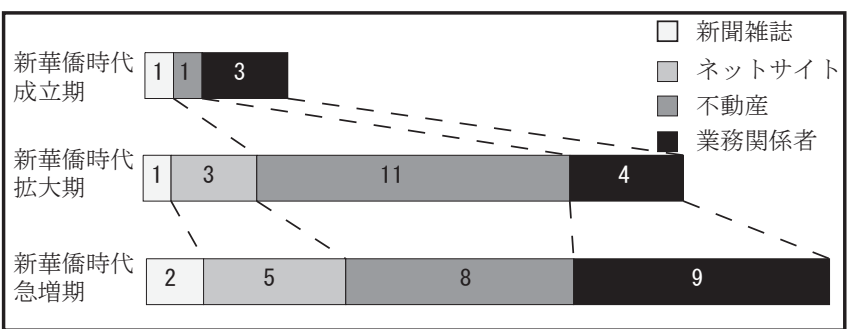

図 8 事業所選定の仲介者

\section{6-2 近隣商店主との付き合い程度}

「挨拶をする程度」という回答は大半で得られた。また、一緒に「事 業所周囲の掃除や環境を維持する」事業所は「駅前立地」と「駅西 立地」の約半数に見られたが、「駅北立地」の事業所では少ない。さ らに、日常業務の交流や飲み会、セールキャンペーンなどの深い交 流を行っている経営者は少なかった（表 10）。

\section{6-3＼cjkstart地縁組織とのつながり}

ここでは地縁組織の内、生活と関わる「町内会」および商売と関 わる「商店会」を取り上げ、華商 $\mathrm{E} ・ \mathrm{~B}$ との関係の実態と変化を以下 にまとめる。

「拡大期」では、中国人の来日のブームの時期であり、多くの中国 人が在日日数の少なさから地縁組織へは加入、参加をしていない。「拡 大期」、「急増期」に入ると、地縁組織に加入したり参加する事業所 が増えているが、華商 $\mathrm{E} ・ \mathrm{~B}$ 事業所の数の増加率と比へ、地縁組織に 携わる事業所の割合は極めて低い（表 11）。その一方、駅前におけ
表 10 類型毎の近隣商店主との付き合いの程度

\begin{tabular}{|c|c|c|c|c|c|c|c|}
\hline & $\begin{array}{l}\text { 挨捘を寸る } \\
\text { 程度 }\end{array}$ & $\begin{array}{c}\text { 日常の業務 } \\
\text { を話してい } \\
\text { る }\end{array}$ & $\begin{array}{l}\text { 飲み会など } \\
\text { でコュニ } \\
\text { ケーション } \\
\text { を图っている }\end{array}$ & 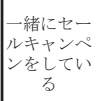 & $\begin{array}{l}\text { 事業所周辺 } \\
\text { の掃除なと } \\
\text { 墂境維持 } \\
\text { をし }\end{array}$ & その他 & $\begin{array}{c}\text { 全く付き合 } \\
\text { }\end{array}$ \\
\hline $\begin{array}{c}\text { 駅前立地 } \\
(\mathrm{N}=26)\end{array}$ & 23 & 2 & 2 & - & 12 & 1 & 1 \\
\hline $\begin{array}{c}\text { 駅北立地 } \\
(\mathrm{N}=11)\end{array}$ & 10 & 1 & 1 & - & 3 & - & 1 \\
\hline 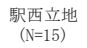 & 14 & 1 & - & 1 & 8 & 1 & 1 \\
\hline
\end{tabular}

る事業所の集中や中国人客の増 表 11 時期毎の地縁組織に携わ 加により、ゴミ出し問題や治安 問題が起きた時期もある。現在 ではゴミ出し問題は改善してき たが、華商 $\mathrm{E} ・ \mathrm{~B}$ 事業所数の急増 に比して「商店会」組織に加入 した事業所数が少ないため、商 店会側が街灯電気代負担を求め る事業所数

\begin{tabular}{|c|c|c|c|c|}
\hline & 成立期 & 拡大期 & 急増期 \\
\hline \multirow[b]{2}{*}{$\begin{array}{l}\text { 町内会 } \\
(\mathrm{N}=4)\end{array}$} & 加入 & 0 & 2 & 2 \\
\hline & $\begin{array}{l}\text { 活動 } \\
\text { 参加 }\end{array}$ & 0 & 3 & 1 \\
\hline \multirow{2}{*}{$\begin{array}{l}\text { 商店会 } \\
(\mathrm{N}=18)\end{array}$} & 加入 & 0 & 2 & 2 \\
\hline & $\begin{array}{l}\text { 活動 } \\
\text { 参加 }\end{array}$ & 0 & 4 & 4 \\
\hline
\end{tabular}
るなどの苦情が出ている注 7)。

また、類型毎にみると、組織に 表 12 類型毎の地縁組織に携わ 加入している事業所は少ないが、る事業所数

「駅前立地」と「駅北立地」と比 べて、「駅西立地」の事業所は組 織に加入しない非正式的な活動参 加が多くなっている（表 12）。

更に、「新華僑時代」に対して、 「老華僑時代」には生活必需品を

\begin{tabular}{|c|c|c|c|c|}
\hline & $\begin{array}{l}\text { 駅前立地 } \\
(\mathrm{N}=26)\end{array}$ & $\begin{array}{c}\text { 駅北立地 } \\
(\mathrm{N}=11)\end{array}$ & $\begin{array}{r}\text { 駅西立地 } \\
(\mathrm{N}=15)\end{array}$ \\
\hline \multirow[b]{2}{*}{$\begin{array}{l}\text { 町内会 } \\
(\mathrm{N}=4)\end{array}$} & 加入 & 1 & 1 & 2 \\
\hline & $\begin{array}{l}\text { 活動 } \\
\text { 参加 }\end{array}$ & 2 & 0 & 2 \\
\hline \multirow{2}{*}{$\begin{array}{l}\text { 商店会 } \\
(\mathrm{N}=18)\end{array}$} & 加入 & 2 & 1 & 1 \\
\hline & $\begin{array}{l}\text { 活動 } \\
\text { 参加 }\end{array}$ & 1 & 1 & 6 \\
\hline
\end{tabular}
供給し、食事やお酒を提供寸るヤミ市があった。その中で、長年に 亘り日本に住み、日本の生活に馴染んだ老華商たちは日常の付き合 いや地縁組織への参加など、通常通りにやっていたようであり、日

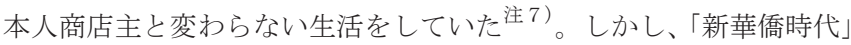
から華商 $\mathrm{E} ・ \mathrm{~B}$ では日本人客の割合が減少していることがわかった。 「拡大期」から中国人客の割合がかなり増えている（図 9)。また業 種毎にみると、「飲食業」に日本人客の割合が高く、中国人客の割合

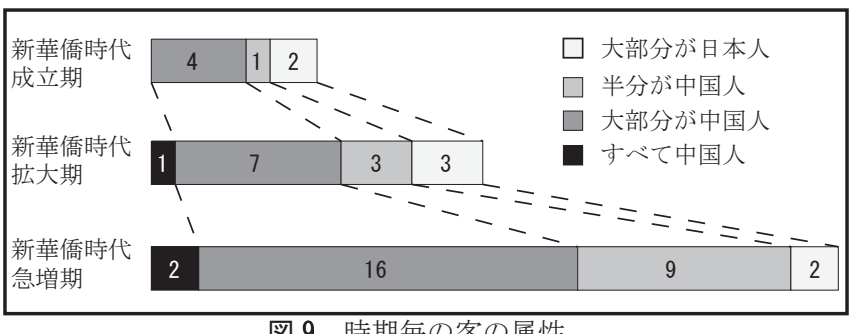

とほぼ同じである。一方、「小売業」「サービス業」は中国人客を中 心に経営していることがわかった（図 10）。つまり、華商 E・B 事 業所の増加と伴い、同胞を主な客とする業種が増えてきて、事業所 の経営は同胞との関係が緊密になっている一方で、日本人とのつな がりが希薄になっている。

\section{6-4 華商 $E \cdot B$ のネットワーク化による地域社会との関係の変化}

華商 $\mathrm{E} \cdot \mathrm{B}$ 事業所は、「拡大期」から 10 人以上の中規模程度の事業 所が増加して（図 11）、その内、中国人の社員を中心とする事業所 


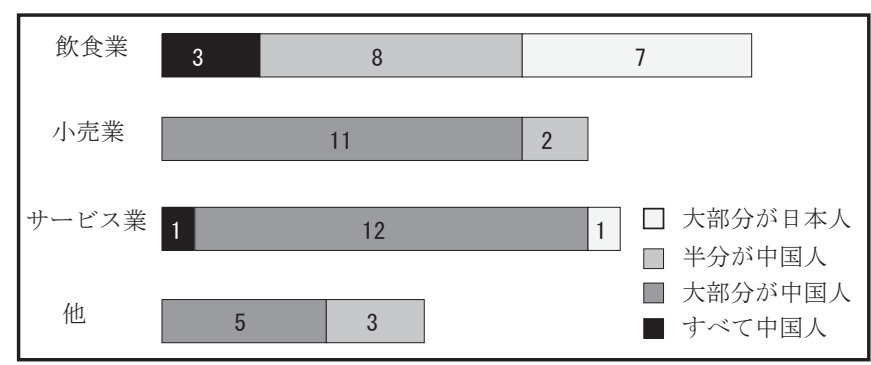

図 10 業種毎の客の属性

の割合がかなり増えている(図 12)。しかし、中国人の経営主体に よる正式な団体が 2008 年までは存在していなかった。2008 年から、 点在する華商 $\mathrm{E} ・ \mathrm{~B}$ 事業所を繋ぐネットワークをつくり、新たな「中 華街」を構築しようという構想注 1 ） の下で、華商 E・B 経営者たち は「東京中華街」という組織を設立した。ヒアリング調査をもとに

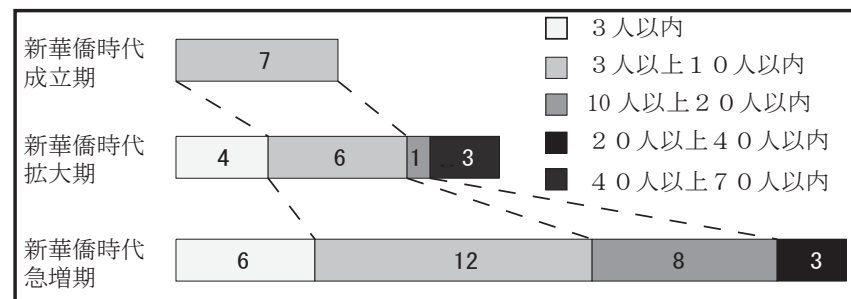

図 11 社員数からみた事業所の規模

注 8)、「東京中華街」の設立のプロセス及び地域との関係の変化を把 握し図 13、14 に示した。なお、「東京中華街」構想は華商 $\mathrm{E} ・ \mathrm{~B}$ 経営 者のネットワークを作ることを出発点として、在日華商 $\mathrm{E} ・ \mathrm{~B}$ 経営者 のイメージアップを図ることで多くの華商 $\mathrm{E} ・ \mathrm{~B}$ 事業所の存在に対し て地元の人々の理解を求めることを主旨としていた。しかし、「東京 中華街」の成立のプロセスの中で、地元の人々との意見交換や交流 が不十分であったため、「東京中華街」の設立によって、「池袋はす べて中国人に占められてしまう恐れがあると考えられ」注 10 ）、地元 の反発を招いた。しかし、華商 $\mathrm{E} ・ \mathrm{~B}$ 経営者の間に何かの組織が立ち 上がることに対しては、商店会側も悪くないと考えている注 7)。

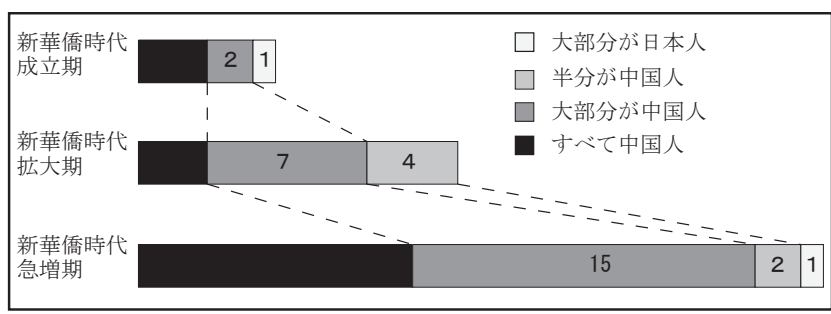

図 12 社員の属性

\section{7 研究のまとめ}

本稿では、池袋北口周辺における華商 $\mathrm{E} ・ \mathrm{~B}$ の集積過程、集積要 因及び地域社会との関係について考察してきた。その結果、大きく 以下の 4 点にまとめることができる。

1 ）池袋北口周辺における華商 $\mathrm{E} ・ \mathrm{~B}$ は 1990 年の入管法改正以降、「成 立期」（1990 ～1997）」、「拡大期」（1998 ～2005）、「急増期」（2006 〜）の 3 つの時期に集積し、その集積が新たな同胞の $\mathrm{E} ・ \mathrm{~B}$ を呼び込 んでいく。

2 ）その集積過程で集積要因、立地環境および駅までの距離により 華商 $\mathrm{E} ・ \mathrm{~B}$ 事業所の分布の特徴が現れている。同胞店舗の集積や駅ま での近さにより、「駅前立地」は多様な業種の事業所が出店し、更な る集中を生み、「駅北立地」は隣接する「駅前立地」に大きな同胞 $\mathrm{E}$ B 集積があるため、集中を加速していく傾向が見られるの対して、「駅 西立地」は「隠れた家の雰囲気」が求められ、飲食業を中心として、 周辺へ分散していることがわかった。また、集積過程では従業員は もとより、客層も華人の比率を高めていき、同胞との関係が緊密化 していく。

3) 一方で華商 $\mathrm{E} ・ \mathrm{~B}$ は町内会や商店会といった地元地縁組織との関 係が希薄化していく。華商 $\mathrm{E} ・ \mathrm{~B}$ が集積していくほどに、空間的にも 心理的にも地元の経営者に圧迫感を与え、地縁組織との交流が不足 する中でのエスニック団体（東京中華街）の立ち上げによって、対 立が生まれている。

$4 ） こ の$ 状況に対して、華商 $\mathrm{E} ・ \mathrm{~B}$ 経営者の地縁組織への無関心や

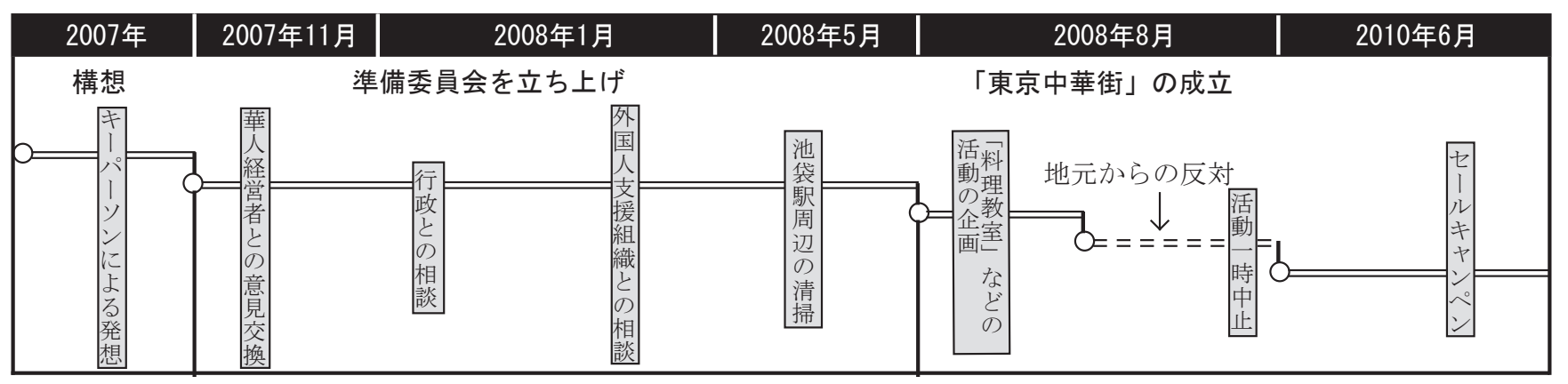

図 13 「東京中華街」設立のプロセス

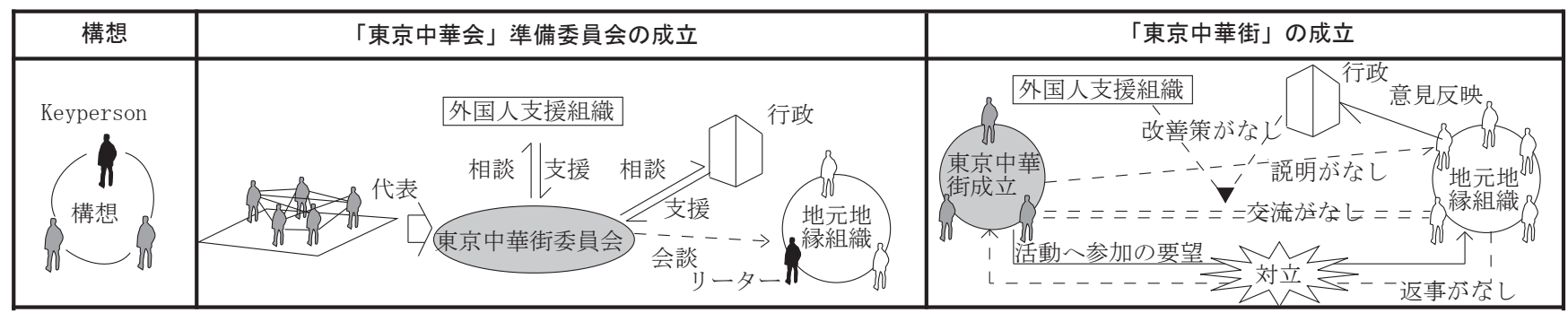

図 14 「東京中華街」設立のプロセスにおける地域との関係の変化 
地元地縁組織自身の改善策および行政の支援がないなどの問題もあ る。その一方、地元商店会も地域経済活性化のために、地縁組織一 の加入を期待し、華商 $\mathrm{E} \cdot \mathrm{B}$ 経営者も対立よりも相互理解や技術交流、 行政支援を望む声も少なからずである。これらを踏まえたうえで、 外国人経営者と地域社会との良好な関係構築を図っていく必要があ るだろう。

\section{注}

注 1) 東京都の人口推計による、平成 21 年 10 月 1 日、区部人口総数が 8854239 人、区部外国人総数が 347336 人、区部中国人総数が 129966 人であ る。東京総務局ホームページ

注 2) 入国管理局ホームページ

注 3）エスニック集団（経営者）が経済的な自立のため、自国同胞や日本人な

どを対象にサービスなどを提供する、エスニック色の強いビジネスである。 注 4) 文献 4

注 5）主に中国語の新聞社、図書出版社および雑誌広告発行の事業所である。

注 6) 山下 清海『地理』第 48 巻第 8 号掲載の論文「世界各地の華人社会の動向」

において「池袋チャイナタウン」という呼称を提案したものである。

注 7)K. Y 氏へのヒアリングによる

注 8)H. YF 氏へのヒアリングによる

注 9) Y. Y 氏へのヒアリングによる

注 10)W. ML 氏へのヒアリングによる

注 11)L.XF 氏へのヒアリングに上る

\begin{tabular}{|c|c|}
\hline \multicolumn{2}{|c|}{ ヘアリング対象者一覧 } \\
\hline 名前 & 役職 \\
\hline K. Y & 池袋北口商店会会長 \\
\hline H. YF & 「東京中華街」理事長 \\
\hline Y. Y & 豊島区区役所産業課商店街振興係長 \\
\hline W. ML & 華商 $\mathrm{E} ・ B$ 事業所 社長 「東京中華街」理事 \\
\hline L. XF & 華商 E・B 事業所 オーナー \\
\hline
\end{tabular}

注 12)「今日の東京の華人社会をみると、もともと老華僑は、日中国交正常化 直前の在留中国人人口である 15,000 人くらいと考えてよい。これに対して、 2006 年には在留中国人人口は 126,498 人となっている。老華僑は、今や在 留中国人の 1 割あまりにすぎず、 9 割近くは新華僑であり、東京の華人社会 は新華僑が中心となっている。学界、メディア、ハイテク産業などで、有能 な新華僑が多数活躍している」（段 躍中 (2005) : 日本の新華僑華人.山下 清海編：『華人社会がわかる本』明石書店, 128-134.)

注 13）「徒歩容易圈」の研究によって、生活圈は 400 - $800 \mathrm{~m}$ であり、容易に 歩行できる距離を $250 \mathrm{~m}$ を設定している。

注 14）業種の多様性は池袋の華商 $\mathrm{E} ・ \mathrm{~B}$ 特徴の一つであり、本稿は『日本標準 産業分類』を参考しながら、事業の内容によって業種用語を以下のように定 義している。

\begin{tabular}{|c|c|c|}
\hline 業 種 & 用語 & 定 義 \\
\hline 飲食業 & 飲食店 & 中華料理を中心とする店舗 \\
\hline \multirow{4}{*}{ 小売業 } & 食料品 & 中国から輸入した食品の販売を中心とする店舖 \\
\hline & 電話パソコン通信 & $\begin{array}{l}\text { 携帯電話、バソコン及び周辺機材の販売、インターネット } \\
\text { 申請などの店舗 }\end{array}$ \\
\hline & 衣服 & 衣服を販売する店舗 \\
\hline & 書店 & 図書を販売する店舗 \\
\hline \multirow{5}{*}{$\begin{array}{l}\text { サービ } \\
\text { ス業 }\end{array}$} & 旅行関連 & 交通、宿泊、その他の旅行商品を仲介して販売する店舖 \\
\hline & 美容・エステ整体 & 結髪、化粧等の方法により容姿を美しくする店舗 \\
\hline & 娛楽業 & 主にカラーオーケーなどの娛楽施設を経営する店舗 \\
\hline & 広告会社 & ホームページーや広告看板の設計や制作する店舗 \\
\hline & 総合事業 & 事業の内容が多様である会社およびグープ会社 \\
\hline \multirow{2}{*}{ その他 } & 不動産 & 不動産販売、賃貸の仲介事業を中心とする店舗 \\
\hline & 銀行 & 中国国内の銀行の海外の支店 \\
\hline \multirow[b]{2}{*}{ 非商店 } & 新聞出版 & 中国語の新聞紙の発行を中心とする会社 \\
\hline & 自動車学校 & $\begin{array}{l}\text { 運転免許を受けようとする者に対して、自動車の運転に関 } \\
\text { する道路交通法規などの知識、そして運転に関する技術を } \\
\text { 教習させる会社 }\end{array}$ \\
\hline
\end{tabular}

注 15）「東京中華街」構想：池袋駅周辺歩行距離 5 分間内、点在の中華のお店 がネットワーク化にする、地理的なブロックではなく、生活圈のネットワー クにして、新たな「中華街」を構築しようということである。池袋での 50 店舗および新宿、大塚などの支店を含め、70 店舖の会員を募集した。

\section{参考文献}

1）稲葉 佳子：公営住宅における外国人居住の実態に関する研究，都市計画論 文集， No. 43-1，pp. 66-72，2008.4

2) 稲葉 佳子: 外国人の民間賃貸住宅入居支援策に関する考察, 都市計画論文 集, No. 40-2，pp. 63-70，2005. 10

3）土田 雅裕、渡辺 貴介：東京都区内における非永住型外国人居住の分布と 形態に関する研究, 都市計画論文集, No. 21-21, pp. 121-126, 1986

4) 山下 清海: 第二次世界大戦後における東京在留中国人の人口変化, 人文地 理学, Vol. 31, pp. 97-113, 2007

5）趙 佳玲、Bernat Agullo Rosello、江川 緑 : エスニックビジネスの発展プ ロセスとソーシャルネットワークに関する研究, 経営行動科学学会論文集 (9) , pp. 294-297, 2006. 11

6）野島 慎二、玉置 伸吾 : 小規模賃貸店舗の展開特性とその集積街区の受け 皿機能に関する研究, 都市計画論文集 (530), pp. 193-200, 2000.4

7）片岡 博美 : 浜松市におけるエスニック・ビジネスの成立・展開と地域社 会，経済地理学年報 50（1）,pp. 1-25, 2004.3

8) 福本 拓: 大阪府における在日外国人ニューカマーの生活空間 : 地理科学 , vol. 57, No. 4, pp. 255-276, 2002

9）まち居住研究会：外国人居住と変貌する街一まちづくりの新たな課題, 京都学芸出版社, 1994.12

10）山下 清海: 池袋チャイナタウン-都内最大の新華僑街の実像に迫る, 洋 泉社, 2010

11）奥田道大ほか：池袋のアジア系外国人一回路を閉じた日本型都市でなく 東京明石書店, 1995.8

12）山下 清海: エスニック・ワールドー世界と日本のエスニック社会, 明石 書店 , 2008

13）山下 清海 : 華人社会がわかる本一中国から社会へ広がるネットワールの歴 史、社会、文化, 明石書店, 2005

14）金原左門ほか：日本のなかの韓国・朝鮮人、中国人：神奈川県内在住外国 人実態調查より，東京明石書店，1986.7

15）東京都豊島区（編集）：豊島区史，1951.6

（2011年 2 月 10 日原稿受理，2011年 8 月26日採用決定） 